\title{
I. ROZPRAWY
}

\author{
Grzegorz Białuński (Olsztyn)
}

\section{$\mathrm{Z}$ przemian społeczno-prawnych na ziemiach pruskich. Problem tzw. oraczy (XV-XVIII wiek)}

W niedawno wydanej książce o Mazurach autorstwa Andreasa Kosserta wspomniano o osobliwości w dziejach osadnictwa południowo-wschodnich Prus, jaką była grupa oraczy, występująca tylko w starostwie ełckim. Uznano ją w drabinie społecznej za warstwę najniżej stojącą, gdyż nie miała jakoby żadnych przywilejów i była w dużej mierze pozbawiona praw. Wsie zamieszkałe przez oraczy miały to być wsie służebne, których było ok. 1500 r. - 12, zaś w 1539 r. - 44¹. Jako że nie jest to odosobniona opinia, a z pewnością niezbyt prawdziwa, warto do problemu raz jeszcze powrócić.

Przyjrzyjmy się najpierw wcześniejszym opiniom o oraczach (Oratzen, Oratschen, Aratzen, Pflüger) w dotychczasowych opracowaniach. Wojciech Kętrzyński nie miał wątpliwości, że oracze byli wolnymi z głównym obowiązkiem w postaci szarwarku polegającego na oraniu pól zamkowych, skąd też wzięła się ich nazwa². Z kolei Christel Moczarski uznała ich za chłopów czynszowych bez określonych praw i przywilejów lokacyjnych ${ }^{3}$. Otto Barkowski podał ponownie, że byli to mali wolni (kleine Freie), którzy zamiast służby wojskowej posiadali obowiązek szarwarku. Zresztą pozostałe obciążenia wyraźnie zbliżały oraczy do wolnych (płuż-

\footnotetext{
${ }^{1}$ A. Kossert, Mazury. Zapomniane południe Prus Wschodnich, przełożyła Barbara Ostrowska, Warszawa 2004, s. 43.

${ }^{2}$ W. Kętrzyński, O ludności polskiej w Prusiech niegdyś krzyżackich, Lwów 1882, s. 264.

${ }^{3}$ Ch. Moczarski, Der Kreis Lyck. Ein ostpreußischer Wirtschaftsraum, Breslau 1938, s. 23.
} 
ne, czynsz rekognicyjny) $)^{4}$. Bernhard Gebauer sprzeciwił się opinii jakoby oracze byli chłopami czynszowymi, jak też jakoby nie posiadali praw, brakowało im jedynie prawa zapisanego przywilejem. Natomiast kierowali się ogólnym prawem zwyczajowym i wszelkie od niego odstępstwa były przez nich uważane za krzywdę. Tak więc ich obowiązki i prawa były określone i znane zarówno im samym, jak i władzy. W źródłach zaliczano ich do małych wolnych, ale przecież różnili się od nich zwiększonym obowiązkiem szarwarkowym, dokładnie takim samym, jaki pełnili chłopi. Gebauer genezę ich widział w organizacji wsi przyniesionej przez litewskich osadników lub ewentualnie miejscowych lub osiadłych Prusów, poza tym tylko ci ostatni jako niewolni nie otrzymywali przywilejów. Zauważył jednak, że później większość osadników w tych wsiach stanowili Mazowszanie, ale musieli to być chłopi, w żadnym wypadku rycerstwo. W sumie opowiedział się za tym, że oracze byli chłopami szarwarkowymi (nie czynszowymi). Ich wsie od wsi czynszowych różniły się organizacją (brak sołtysów) i brakiem niemieckiego prawa. Wprowadzenie niezwykłej służby szarwarkowej zamiast wojskowej wyjaśniał brakiem zapotrzebowania na tę pierwszą po wojnie trzynastoletniej, a więc wtedy, kiedy powstawały pierwsze osady oraczowskie ${ }^{5}$. Zgodnie z nomenklaturą źródeł za małych wolnych uznał oraczy także Reinhold Weber ${ }^{6}$. W najnowszej polskiej literaturze uchodzą jednak ciągle za chłopów ${ }^{7}$. Pogląd ten staraliśmy się obalić we wcześniejszych pracach. Według naszych ustaleń oracze byli małymi wolnymi, którzy zamiast obowiązku służby zbrojnej mieli obowiązek wystawiania służby oraczowskiej. Ich pozycja społeczna (i ekonomiczna) była zbliżona do wolnych, choć w świadomości ówczesnych mieszkańców była ona nieco niższa (bycie wolnym było bardziej pożądane). Swoje majątki posiadali oracze bez przywilejów lokacyjnych, ale kierowano się wobec nich prawem magdeburskim prostym $^{8}$.

${ }^{4}$ O. Barkowski, Quellenbeiträge zur Siedlungs- und Ortsgeschichte des Hauptamtes Stradunen-Oletzko, „Altpreussische Forschungen“, 1936, Jg. 13, s. 200.

5 B. Gebauer, Die Entwicklung der Siedlunglandschaft in Süd-Ostmasuren (Kreis Lyck), unter besonderer Berücksichtung der Siedlungsgenese. Ein Beitrag zur Kulturlandschaftsordnung im deutschen Osten, Göttingen 1959 (maszynopis), s. 46-54.

${ }^{6}$ R. Weber, Die Landgemeinde des Grenzkreises Lyck, Hohenwestedt 1988, s. 638; idem, Der Kreis Lyck, Leer 1981, s. 86.

${ }^{7}$ Por. J. Małłek, Stup graniczny w Prostkach z roku 1545 symbolem wspótżycia sasiadów po jego obu stronach, [w:] Przeszłość natchnieniem dla teraźniejszości. Sympozjum historyczne i świętowojciechowe. Ełk, 20-22 kwietnia 1994 roku, Ełk 1996, s. 106; J. Kopciał, Kalinowo. Monografia gminy, Suwałki 1994, s. 127.

${ }^{8}$ G. Białuński, Bevölkerung und Siedlung im ordensstaatlichen und herzoglichen Preussen im Gebiet der "Grossen Wildnis" bis 1568, Hamburg 2009, s. 377-382; idem, Przemiany spoleczno-ludnościowe poludniowo-wschodnich obszarów Prus Krzyżackich i Książęcych (do 1568 roku), O1sztyn 2001, s. 220-226. Pierwsza część niniejszego artykułu została oparta na tych właśnie pracach. 
W źródłach oraczy z nazwy wzmiankowano po raz pierwszy w $1519 \mathrm{r}$. (Oratschen $)^{9}$. Jednak pierwsze osady oraczowskie odnotowano już w latach siedemdziesiątych XV w. Prawie wszystkie powstały w czasach krzyżackich, potem już tylko dwie (Sędki i Ropele). W 1521 r. istniało aż 47 dóbr oraczowskich, z których jednak 6 przekazano następnie wolnym (Szeligi, Kulisze, Karbowskie i Rostki) lub szlachcie (Dzydzusze, Myszkakuntz). Ostatecznie więc w 1568 r. funkcjonowały 43 dobra oraczowskie ${ }^{10}$. Do tego trzeba dodać jedne dobra położone po 1519 r. w starostwie straduńskim (Oracze, wcześniej Somayten). W sumie oracze stanowili $18 \%$ całej ludności w starostwie ełckim i posiadali aż $26 \%$ areału uprawnej ziemi.

Z obowiązków oraczy na czoło wysuwa się służba oraczowska. Jedną służbę wystawiano od każdych posiadanych 15 łanów, a dalej odpowiednio połowę od 7,5; zaś dwie od 30 łanów. Najpełniejszy opis obowiązków oraczowskich zachował się w jednej z ksiąg zamkowych z połowy XVI w. ${ }^{11}$ Tutaj podajemy go według nieco poprawionego thumaczenia W. Kętrzyńskiego ${ }^{12}$ : „Oracze - każdy z nich ma 15 łanów, z których czyni jedną służbę; nie mają przywilejów lokacyjnych, lecz tylko listy kupna. Obowiązkiem ich jest oranie pól folwarcznych pod oziminę i zboże jare, wykonywanie wszelkich budowli folwarcznych, stawianie płotów polnych, koszenie trawy z jednej morgi, zebranie jej i zwożenie na zamek ełcki. Obowiązani są [też] dawać od każdego dymu ${ }^{13}$ korzec pszenicy i korzec żyta oraz funt wosku od każdej służby. Wożą również na zamek $3 / 4$ fury drewna od każdej służby, a jeżeli to nie wystarczy, to powinni zwieść dwie fury od każdego dymu". Ten bardzo szczegółowy opis ich obowiązków można uzupełnić o inne jeszcze przekazy. W popisie wojskowym w 1519 r. od każdej służby żądano wystawienia pół wozu oraz jednego konia (oczywiście z oraczem) ${ }^{14}$. Tak więc do służby wojskowej także byli pociągani, jednak sposobem zbliżonym do chłopów. Wreszcie w listach kupna dla oraczy z Sędek i Ropel z 1548 r. wymieniono szczegółowo zakres ich obowiązków. Mieli więc pełnić szarwark na dworze w Ełku, wnosić daninę płużną (w sumie po 5 korców żyta i pszenicy), w wosku (po pół funta),

${ }^{9}$ Geheimes Staatsarchiv Preussischer Kulturbesitz, Berlin (dalej GStAPK), Ordensbriefarchiv (dalej OBA) nr 22935.

${ }^{10}$ Nadto pojedynczych oraczy odnotowano w $1561 \mathrm{r}$. w dobrach wolnych, mianowicie w Guzkach i Siedliskach, por. GStAPK, Etats-Ministerium (dalej EM) 93e 2, nr 31.

${ }^{11}$ GStAPK, Ostpreussische Folianten (dalej Ostpr.Fol.) 119, f. 87.

12 W. Kętrzyński, op.cit., s. 265.

${ }^{13} \mathrm{~W}$ tym wypadku chodziło o dym w znaczeniu jednego gospodarstwa, potwierdza to sformułowanie z popisu wojskowego w 1519 r., gdzie zanotowano von itzlichen pflug 1 scheffel weys und 1 scheffel korns (OBA nr 22935, s. 337). Wiadomo natomiast, że pług (Pflug) oznaczało właśnie pojedyncze gospodarstwo. O takim rozumieniu pojęcia „dym” zob. H. Łowmiański, Zaludnienie państwa litewskiego w wieku XVI. Zaludnienie w roku 1528, Poznań 1998, s. 131-132.

${ }^{14}$ OBA nr 22935, s. 337, 356. 
ciąć i zwozić na zamek drewno (po $1 / 4$ fury) ${ }^{15}$. Potwierdzały one znane nam już obciążenia, nieco niższy był jedynie obowiązek zwózki drewna. Odosobnionym przykładem byli oracze z Sikor, których obowiązkiem było wyrabianie klepek na potrzeby zamku ełckiego, za to byli wolni od służby oraczowskiej. W XVI w. okazało się jednak, że ówcześni mieszkańcy nie byli zdatni do takiej pracy, w związku z tym uwolniono ich od niej, jak też od pańszczyzny ręcznej oraz zwózki drewna (1564 r.). W zamian mieli jednak dawać rocznie 7 grzywien celem najmowania budników, którzy wyrabialiby klepki zamiast nich. Musieli też zwozić 45 korców owsa do spichlerza w Królewcu za wynagrodzeniem 5 szelągów od korca. Utrzymano też obowiązek wnoszenia płużnego oraz koszenia i zwożenia siana z obszaru o wielkości 1 morgi do obory folwarcznej lub owczarni ${ }^{16}$. Oracze z jedynej wsi oraczowskiej w starostwie straduńskim byli pociągani do budowy, naprawiania i czyszczenia wszelkich kominów w folwarkach dominialnych ${ }^{17}$.

Porównajmy teraz te obowiązki z chłopami i wolnymi. Niewątpliwie szarwark przypomina ten chłopski, ale $\mathrm{z}$ drugiej strony był zupełnie inaczej zorganizowany, mianowicie na podobieństwo służby wojskowej wolnych (człowiek, koń i, zamiast zbroi, sprzężaj od każdej służby). Najprawdopodobniej nie było bowiem tak, że wszyscy oracze byli zobowiązani do szarwarku ornego, ale jeden z każdych 15 łanów przez nich posiadanych. To właśnie była wspominana w źródłach służba $(\text { Dienst })^{18}$. Pozostali natomiast byli obciążani jego utrzymaniem i z pewnością pełnili wszystkie pozostałe robocizny (Scharwerk). Kolejne obciążenie w postaci płużnego również było oddawane sposobem wolnych (od gospodarstwa, a nie od liczby łanów). Wnosili też daninę z wosku, która była charakterystyczna także tylko wolnym. Wykonywanie budów było też obowiązkiem powszechniejszym wśród wolnych, jedynie stawianie płotów, zwózka drewna i koszenie trawy były typowo chłopskim obciążeniem, ale również, choć rzadko, spotykane u wolnych. $\mathrm{Z}$ tego możemy wnioskować, że oracze pod względem obowiązków byli raczej wolnymi niż chłopami.

Zwróćmy też uwagę na umiejscawianie oraczy przez współczesne źródła, przecież najbardziej miarodajne. W 1519 r. wydzielono oraczy od wolnych i chłopów czynszowych, ale zapisano ich jako: Freyen araytzen ${ }^{19}$. Wydzielono ich rów-

${ }^{15}$ Ostpr.Fol. 119, f. 88 i n.

${ }^{16}$ Ostpr.Fol. 229, f. 62; W. Kętrzyński, op. cit., s. 464; H.H. Diehlmann, Die Dienstgüter Die Dienstgüter des Amtes Rein in Preussen, Bd. 4: Die von Krösten auf Reuschendorf, Miedzen und Pistzken (maszynopis), Th. 2, s. 579.

${ }_{17}$ EM 103h, f. 2.

${ }^{18}$ W 1662 r. określono ich jako wybrańców (Wiebrantzen), Ostpr.Fol. 6498. W 1558 r. Michał Kulesza wyraźnie rozróżniał służbę od szarwarku, EM 93d, nr 52, f. 5: Dienst und Scharwerk thue; den Scharwerk mit sampt den Dienst.

19 OBA nr 22935, s. 337. 
nież w księdze rachunkowej z 1600 r., tutaj określono ich jako: Kleynen Freyen, sonsten Oratzier oder Pflüger ${ }^{20}$. Przesłanki te wskazują, że współcześnie traktowano oraczy jako oddzielną grupe społeczną, ale równoważną małym wolnym.

Kolejną przesłankę o pozycji oraczy zbliżonej do wolnych odnajdujemy w stawkach podatkowych. W $1561 \mathrm{r}$. oracze dawali dziesięcinę w wysokości 15 szelągów od domu (gospodarstwa), a podatek szkolny w wysokości 8 szelągów. W tym czasie wolni dawali 20 szelągów od dworu (gospodarstwa), zaś chłopi czynszowi 15 szelągów, ale od każdego łanu ${ }^{21}$. Tak więc były to stawki bardziej zbliżone do wolnych, potwierdzają to zresztą nieco późniejsze przekazy. Otóż w latach siedemdziesiątych i osiemdziesiątych XVI w. dziesięcinę oraz podymne wnosili już w takiej samej wysokości, jak wolni, tj. 13 szelągów od łanu oraz 8 szelągów od dymu ${ }^{22}$. Najwięcej danych na temat ich sytuacji społeczno-ekonomicznej dostarczają jednak wykazy podatkowe tzw. Nachtgeldu z 1539 r. Najbogatsi oracze zostali wycenieni na ponad 30 Nacht (Piotr z Przepiórek na 31,5), przeważały jednak stawki wynoszące po kilkanaście Nacht (średnia wynosiła 11,1; ale z zagrodnikami) ${ }^{23}$. Zdarzały się jednak osoby wycenione zaledwie na 1-2 Nacht (Jan Juda w Skomętnie Małym; Jan Dobeck w Stożnych; Paweł Sdun w Baranach, Wojtek Schurillo w Pistkach). W sumie średnia stanu hodowli zbliżała ich ponownie do wolnych (średnia 11, zaś chłopów 8 Nacht, w obu przypadkach z zagrodnikami). Dodajmy też, że przeciętne gospodarstwo oracza wynosiło 1,7 łanu; co również zbliżało go do wolnego (2 łany, zaś chłopa poniżej 1 łanu). Mimo wszystko pozycja wolnych była w poczuciu mieszkańców wyższa. Wskazuje na to chociażby przykład Michała Kuleszy, który (z sukcesem) zabiegał o zmianę statusu swoich dóbr z oraczowskich na wolne (Kulisze). Wolał dawać rocznie 15 korców owsa oraz wystawiać konia pociągowego niż pełnić dotychczasową służbę oraczowską i szarwark ${ }^{24}$.

Rozpatrzę jeszcze kwestię sytuacji prawnej oraczy. Wobec tego, że nie otrzymywali oni przywilejów lokacyjnych, nie mieli jasno określonego prawa. W 1531 r. określono je jako „dobra pruskie” (preusch gutter). Wtenczas starosta ełcki Krzysztof von Zedwitz informował kancelarię książęcą o zasadach spadkobrania w przypadku takich dóbr, w związku z wsią Dudki (zob. aneks źródłowy). Zasady te określono następująco: córki miały być wyposażone przy zamążpójściu, dobra po śmierci właściciela i jego dzieci przypadały księciu, zaś wdowa

${ }^{20}$ Ostpr.Fol. 6491.

${ }^{21}$ EM 93e 2, nr 31 (parafia ełcka).

${ }^{22}$ Ostpr.Fol. 1283; EM 93d, nr 113 (1588 r.): Ziemianie, ktorzi maja wloki od czinszu wolne, ci od wloki po 13 szilingów kościelnego dają, a po 8 schilingów skolnego, a po temusz i Oracze.

${ }_{23}$ Ostpr.Fol. $911 \mathrm{a} / 17$.

${ }^{24}$ EM 93d, nr 52, f. 5 (1558); swoją prośbę uzasadniał m.in. tym, że liczba oraczy była już wystarczająca. 
miała zatrzymać przyodziewek i domowe ruchomości, czyli najpewniej rzeczy podręczne, które były związane z jej codzienna pracą. Jeśli dobra zostałyby decyzją ojca podzielone między dwóch lub trzech synów, a następnie jeden z nich zmarłby, to jego część przypadała księciu. Prawo pierwokupu tej części należało jednak do jego naturalnych spadkobierców lub najbliższych krewnych. Podsumowując, w przytoczonej informacji stwierdzono, że wobec powyższego losy puścizny w Dudkach zależały od woli księcia, mógł je ponownie komuś nadać lub włączyć do majątku książęcego ${ }^{25}$. Faktycznie takie postępowanie przypominało zasady znane z prawa pruskiego - spadkobranie przez synów, zakaz dziedziczenia przez braci i wyposażenie córki. Problem w tym, że późniejsze źródła wyraźnie jednak wskazują, że oracze swoje łany posiadali na prawie magdeburskim prostym ${ }^{26}$, a więc prawie typowym na tym obszarze dla małych wolnych. Trzeba zauważyć, że zasady określone w $1531 \mathrm{r}$. były zbieżne również z prawem magdeburskim - wyposażanie córek, dziedziczenie przez synów, prawo kaduka w razie śmierci męskich właścicieli i zakaz dziedziczenia po bracie. Należy więc wnioskować, że nawet władza zwierzchnia miała problemy z określeniem prawa dóbr oraczowskich, które wpierw uznano za pruskie, ale potem opowiedziano się za bardziej adekwatnym dla tutejszych wolnych prawem magdeburskim prostym.

Zachowały się przykłady spadkobrania w dobrach oraczowskich. W razie młodocianego wieku spadkobiercy majątkiem mogła zarządzać wdowa. Pokazuje to przykład Mikołaja z Szarejek. Jego ojciec zmarł, gdy miał zaledwie 1 rok. Matka zamieszkała w Piszu, zaś jego dziedzictwo (1,5 łanu) oddała wówczas w użytkowanie niejakiemu Pawłowi Szarejce. Ten jednak po jakimś czasie sprzedał swoje dobra wraz z owym 1,5 łanem. Gdy Mikołaj doszedł do pełnoletności, zaczął starania o należny mu zwrot jego dziedzictwa ${ }^{27}$. Podobnie jak w dobrach wolnych na prawie magdeburskim za zgodą władz i odpowiednią zapłatą było możliwe przejęcie dóbr przez córki lub siostry. Taki przypadek miał miejsce w Przepiórkach w 1552 r. Niejaki Stanisław nabył tam gospodarstwo liczące 2,5 łanu, które po jego śmierci objęli dwaj synowie, również wkrótce zmarli. W majątku pozostały dwie siostry Barbara i Małgorzata, córki Stanisława. Majątek został jednak przejęty przez księcia, choć siostrom zezwolono na gospodarowanie tymi dobrami, oczywiście za wypełnieniem należnych obowiązków. Po czterech latach jednak starosta nakazał siostrom wpłacenie 100 grzywien jako należnej zapłaty i do tego czasu nie pozwalał na gospodarowanie dobrami. Siostry prosiły o możliwość gospodarowania zanim zostanie uiszczona opłata, na co starosta nie wyraził zgody, a nawet skonfiskował im woły, konie i krowy. Przy tym siostry uzasadniały swo-

\footnotetext{
25 EM 93d, nr 22, f. 1.

26 Ostpr.Fol. 6491 i Ostpr.Fol. 6498.

27 EM 93d, nr 145, f. 1 (1543).
} 
je prawa dziedziczne do dóbr nabytych i zapłaconych przecież przez ich ojca ${ }^{28}$. Jednak starosta wspierał się tutaj wyraźnie prawem magdeburskim, które córkom nie gwarantowało dziedziczenia, a jedynie za zgodą księcia dawało im możliwość zakupu rodzinnych majątków. Można więc stwierdzić, że dobra oraczowskie po początkowej niepewności i próbie utożsamienia ich z prawem pruskim, ostatecznie przypisano prawu magdeburskiemu prostemu.

Trudno na podstawie zachowanych źródeł określić genezę oraczy. Tym bardziej, że występowali oni tylko na ograniczonym obszarze jednego starostwa. Według informacji starosty von Zedwitza z 1531 r. określono je jako preusch gutter ${ }^{29}$. Wydaje się jednak wątpliwe, aby rzeczywiście chodziło tutaj o wsie zamieszkałe przez Prusów, aczkolwiek pozornie thumaczyłoby to np. brak przywileju, bo ten rzeczywiście nie występował przy wsiach pruskich ${ }^{30}$. Pojawiają się jednak oczywiste wątpliwości. Akurat w okolicach Ełku ludności pruskiej nie było zbyt dużo, zresztą gdyby przyjąć pruskie pochodzenie wsi oraczowskich Ełckie stanowiłoby swoistą oazę ludności pruskiej. Tego nie potwierdzają żadne źródła (historyczne, językowe ani archeologiczne). Wreszcie przywileje rzeczywiście nie występowały, ale tylko w poddańczych wsiach pruskich, zaś w przypadku oraczy, jak to uzasadniłem powyżej, mamy do czynienia z ludnością wolną. Najpewniej więc powyższego zwrotu o ,pruskich dobrach” w 1531 r. użyto wobec zbliżonych sposobów dziedziczenia, bo przecież ostatecznie nawet uznano te dobra za magdeburskie.

Szukając wyjaśnienia genezy oraczy należy zwrócić uwagę na trzy elementy: występowanie ich tylko w okręgu ełckim (wieś Oracze pierwotnie też wykazano w tym okręgu); brak przywilejów oraz występująca służba oraczowska zamiast wojskowej. Warto więc spojrzeć na nie dokładniej, zwłaszcza na ten drugi element. Bez przywilejów osadzano jeszcze ludność pochodzenia litewskiego. Tak było ze wsiami czynszowników w starostwie węgorzewskim, jak też innymi osadami w starostwie wystruckim ${ }^{31}$. Czyżby więc należało wiązać powstanie osiedli oraczowskich z Litwinami, jak chciał już B. Gebauer? Wydaje się jednak, że taki wniosek byłby nadużyciem. Wystarczy bowiem zwrócić uwagę na takie elementy, jak nazewnictwo miejscowe i osobowe. Fakt, że przynajmniej 7 nazw miejscowości można uznać za litewskie (Burnie, Mołdzie, Śniepie, Szarejki, Judziki, Mącze, Dzydzusze), ale 14 za ewidentnie polskie (np. Długie, Niedźwiedzkie, Jędrzejki, Czarne Mikołaje, Białojany, Cybulki, Sikory). Przeglądając nazewnictwo osobo-

${ }^{28}$ EM 93d, nr 131, f. 1.

${ }^{29}$ EM 93d, nr 22, f. 1.

${ }^{30}$ Por. R. Stein, Die Umwandlung der Agrarverfassung Ostpreußens durch die Reform des neunzehnten Jahrhunderts, 1 Bd.: Die ländliche Verfassung Ostpreußens am Ende des achtzehnten Jahrhunderts, Jena 1918 (II wyd. Hamburg 1997), s. 395.

${ }^{31}$ O. Barkowski, op.cit., s. 173 i n. 
we nietrudno zauważyć, że przewagę miały nazwy typowo polskie i to zarówno w imionach, jak i w przezwiskach oraz nazwiskach. Nie można więc wiązać genezy oraczy oraz braku przywileju tylko z ludnością pochodzenia litewskiego.

Pojedyncze przykłady osadzania mieszkańców bez przywilejów spotykamy również i na pozostałym obszarze, np. w okolicach Pisza w początkach XVI w. Tutaj dwie osady w ogóle nie posiadały żadnych przywilejów (Krzywińskie i Taczki), a 10 osad tylko listy kupna na ogół bez określonego prawa nadania. Potem wszystkim tym osadom uznano prawo magdeburskie proste (np. Ciernie, Nowaki, Krzywińskie), a co więcej wszystkie one były dobrami wolnymi. W niektórych z nich mamy poświadczonych osadników litewskich (Kibisy, Taczki), ale W większości siedzieli również Polacy. W okręgu piskim wymagano jednak od wszystkich służby wojskowej, podobnie jak od pozostałych tego typu osad w innych okręgach ${ }^{32}$.

Należy więc bliżej przyjrzeć się sytuacji wewnętrznej w okręgu ełckim. Pierwsze osady oraczowskie pojawily się tuż po wojnie trzynastoletniej (1454-1466), najpewniej w latach siedemdziesiątych. Wówczas w okręgu istniały zaledwie trzy wsie czynszowe oraz ponad dwadzieścia dóbr służebnych. Wobec dalszego intensywnego napływu osadników ówczesne kierownictwo prokuratorii (za czasów Waltera von Kökeritza ${ }^{33}$ ) musiało zdecydować się na rozwiązanie problemu dysproporcji między zapotrzebowaniem na siłę roboczą w domenie a zbędnością służb rycerskich. Tutaj nasuwa się pytanie, dlaczego więc nie powstały wsie czynszowe? Dobrym tego wytłumaczeniem zdaje się być fakt, że osadnicy ci byli rycerskiego pochodzenia ${ }^{34}$. Najdogodniejszym wyjściem dla obu stron było utrzymanie statusu osadników za cenę zmiany służby wojskowej na oraczowską. Prawdopodobnie była to inicjatywa miejscowa, wywodząca się z kręgów prokuratora von Kökeritza i stąd miało ograniczony terytorialnie zasięg. Wobec tak niezwykłego rozwiązania nie wystawiano im też przywilejów lokacyjnych ${ }^{35}$, a poprzestano na wydaniu odpowiednich listów kupna, które nie zachowały się, poza

${ }^{32}$ Tak było w okręgu giżyckim z Czyprkami i Miechami, w okręgu straduńskim z Hejbutami, Pamrami, Wilkasami i Szeszkami, a w ryńskim - z Miłuszami.

${ }^{33}$ Walter von Kökeritz prokuratorem był w latach 1468-1477, ale najpewniej znacznie dłużej, gdyż wspomniano go również w 1485 r. W gronie jego współpracowników można wymienić burgrabiego Piotra Skarżyńskiego, kompana Jan Streumera i innych braci wspomnianych w konwencie w tym czasie (Kaspar Schaldorfer, Barthel von Stein, Jan von Sturmfeder, Gabriel von Vestemberg, Maciej von Weiler oraz Jan von Weylau).

${ }^{34}$ Według późniejszych spisów wśród oraczy występują takie nazwiska rycerstwa mazowieckiego, jak m.in. Karbowscy, Olszewscy, Grajewscy, Brunakowie i Świdrowie.

${ }^{35}$ Nie były to przecież ani dobra służebne, ani też wsie czynszowe, może więc po prostu brakowało odpowiedniej formuły dokumentu na takie dobra. Poza tym chcę zwrócić uwagę, że decyzje o wystawieniu listu kupna zapadały na niższym szczeblu (prokuratorii), zaś przywileje wystawiały dopiero władze centralne i komturie. 
dwoma wyjątkami. Podkreślę jednak, że niniejsze uwagi w kwestii genezy oraczy stanowią jedynie konstrukcję hipotetyczną.

Przyjrzyjmy się teraz jakie były ich dalsze losy. Według księgi rachunkowej z przełomu XVI i XVII w. (1600-1601) pozycja oraczy jako małych wolnych $\mathrm{z}$ dobrami na prawie magdeburskim nie była jeszcze zagrożona (die Kleynen Freyen sonsten Oratzien oder Pflüger genanndt), choć obciążenia wzrosły i coraz bardziej upodabniały ich do chłopów. Mieli oni pełnić w sumie 39,5 służby oraczowskiej w folwarkach książęcych w Ełku i Nowej Wsi Ełckiej, ponadto wraz $\mathrm{z}$ chłopami mieli pełnić szarwark przy wszelkich pracach budowlanych $\mathrm{w}$ folwarkach, owczarniach i młynach oraz przy pracach w cegielniach i wapniarniach, jak też dbać o ogrodzenia i płoty na polach folwarcznych. Z innych obowiązków oraczy wspomniano (od każdej służby): koszenie trawy i zwożenie na dwór siana z 1 morga ziemi oraz 3 wiertli drewna opałowego z książęcych lasów. Na każde zawołanie starosty mieli też służyć przewozem do Królewca zboża i innych towarów ze starostwa. Jak też zaznaczono, poprzedni władca (zatem książę Albrecht Fryderyk, 1568-1578) narzucił na oraczy obowiązek wnoszenia corocznie czynszu w wysokości 10 groszy od 1 łanu. Ten drobny z pozoru obowiązek diametralnie zmieni wkrótce pozycję społeczną oraczy, upodabniając ich do chłopów czynszowych. Dla uznania zwierzchności władzy książęcej wnosili od każdej służby czynsz rekognicyjny w wysokości 1 funta wosku i 1 denara, czyli podobnie jak wolni, oraz płużne w wysokości 1 korca pszenicy i tyluż żyta od każdego dymu (gospodarstwa) ${ }^{36}$.

Obciążenia oraczy (Oratiern oder Pflügen) znacznie wzrosły w XVII w., co wnosimy z ksiąg rachunkowych z 1662 r. Służbę określano tutaj jako wybraniecką (Wiebrantzen dienst), co dobrze oddawało charakter tej służby, ale chyba też nawiązywało do podobnie wówczas nazywanej służby wojskowej chłopów ${ }^{37}$. Czynsz decyzją komisarzy elektorskich z 1632 r. wzrósł do 1 grzywny od łanu w przypadku pełniących służbę oraczowską i do 4 grzywien w przypadku pozostałych oraczy. Tym ostatnim na mocy decyzji komisarzy elektorskich z $1653 \mathrm{r}$. podwyższono czynsz o kolejne 3 grzywny. W ten sposób znaczna część oraczy w zamian za podwyższony czynsz została faktycznie zwolniona od służby oraczowskiej. W 1632 r. zmienił się też wymiar płużnego, który teraz miał być wnoszony od każdych 2 łanów (nie od gospodarstwa), jak też wymiar dostarczanego drewna opałowego na achtel z każdych 5 łanów. Ponadto od 1649 r. zostali obciążeni czynszem w wysokości 3 groszy od łanu w zamian za sianokosy, opłatą 1 grosza na utrzymanie woźnego sądowego (böttelgeld) oraz opłatą 35 groszy na

36 Ostpr.Fol. 6491.

${ }^{37}$ S. Augusiewicz, Przebudowa wojska pruskiego w latach 1655-1660. U źródet wczesnonowożytnej armii, Oświęcim 2014, s. 59. 
utrzymanie garnizonu wojskowego w Kłajpedzie ${ }^{38}$. Wzrost obciążeń spowodował liczne skargi oraczy, które jednak pozostawały nieskuteczne. W 1678 r. skargę do elektora Fryderyka Wilhelma z powodu wnoszenia opłaty pieniężnej na podwody pocztowe oraz zwiększone obowiązki orki polnej napisali oracze z Miłuk. W następnym roku skargę do starosty wysłali oracze z Przepiórek i Stożnych, skarżąc się na zbyt duże obciążenia. W 1698 r. wszyscy poddani ze wsi oraczowskich wystosowali prośbę o potwierdzenie ich dotychczasowych obowiązków, zapewne licząc na powstrzymanie ich dalszego wzrostu ${ }^{39}$. Należy jednak zaznaczyć, że wzrost obciążeń dotyczył też innych warstw społecznych i także one wnosiły do władz liczne żale i skargi.

W kolejnej zachowanej księdze rachunkowej z lat 1694-1695 oracze po raz pierwszy zostali wymienieni wspólnie z chłopami czynszowymi (Bey den Zins Orratier und Pauerdörfer $)^{40}$. Tak już zostało, przy tym czasami bez specjalnego rozróżnienia osad, które były wsiami oraczowskimi, a które chłopskimi ${ }^{41}$. $\mathrm{Na}$ początku XVIII stulecia doszły jeszcze nowe obciążenia (według ksiąg rachunkowych z lat 1716-1717). Generalnie nastąpiła reluicja obciążeń na gotówkę, i tak zamiast daniny w naturze czy robocizny wnoszono odpowiednie czynsze w pieniądzu (np. zamiast wosku, szarwarku, drewna, sianokosów). Z nowych czynszów odnotować należy opłatę na instygatora, czyli oskarżyciela publicznego (Instigatorgeld $)^{42}$, na podwody pocztowe (Postfuhrgeld), na przędzę (Haspelgarn), na chmiel (Hopfengeld) oraz na pomocnika-robotnika (Handlangergeld) i na opłacenie czeladzi (Gesindlohn), zatrudnianych na potrzeby folwarków dominialnych. W naturze wnoszono tylko zboża, w tym doszła dostawa tzw. ziarna pilawskiego (Pillauische Korn), na potrzeby twierdzy w Pilawie. Czynsz ten nie różnił się od chłopskiego, poza opłatą na rybołówstwo i niekiedy większymi daninami w naturze (drewno). Oracze i chłopi zobowiązani byli też do opłat na rzecz utrzymania garnizonów. Właśnie w tej księdze rachunkowej z lat 1716-1717 oraczy jako takich wspomniano po raz ostatni ${ }^{43}$.

Na marginesie warto zauważyć, że jedyne osiedle oraczowskie, Oracze w starostwie straduńskim, potem oleckim, zawsze zaliczano do wsi wolnych. W księgach starościńskich z 1600/1601 r. podkreślono brak przywileju, brak obowiązku wnoszenia przez mieszkańców wosku i czynszu rekoginicyjnego oraz pełnienia służby wojskowej, natomiast odnotowano obowiązek wnoszenia płużnego po jed-

38 Ostpr.Fol. 6498.

39 B. Gebauer, op.cit., s. 53.

40 Ostpr.Fol. 6505.

41 Ostpr.Fol. 6508.

42 O urzędzie tym szczególnie ważnym dla sądownictwa na pograniczu Prus, zob. R. Stein, op.cit., s. 155. Potem instygator doglądał też poboru akcyzy.

43 Por. B. Gebauer, op.cit., s. 53. 
nym korcu pszenicy i jednym korcu żyta oraz pełnienia szarwarku w folwarku straduńskim w postaci orki polnej. W zamian za to wszystko mieszkańcy zwolnieni zostali od udziału w żniwach ${ }^{44}$, a w 1664 r. byli zwolnieni także z szarwarku w zamian za opłatę w wysokości 60 grzywien ${ }^{45}$. Pod koniec XVIII w. określono wieś jako wieś chełmińską (Cölmische Dorf) $)^{46}$, co w ówczesnej nomenklaturze oznaczało wieś wolnych ${ }^{47}$. Zatem tutaj oracze przeszli do warstwy wolnych.

Rozpatrując pozycję społeczną oraczy warto spojrzeć na listy hołdowników podczas objazdów hołdowniczych przy zmianie władcy w Prusach. Okazuje się, że hołd składali przedstawiciele szlachty, wolnych i tzw. kulmerów (czyli wolnych z dóbr na prawie chełmińskim), mieszczan (także tych z miasteczek bez przywileju lokacyjnego), karczmarzy, sołtysów, natomiast oracze, tak jak chłopi czynszowi, hołdu nie składali. Nie ma ich już w pierwszym wykazie hołdowniczym z 1593 r. ${ }^{48}$ Nie do końca jest to jednak obraz właściwy, gdyż wcześniej, mianowicie podczas hołdu złożonego księciu pruskiemu Albrechtowi w 1555 r. oracze jednak występowali, obok szlachty, wolnych, sołtysów i karczmarzy ${ }^{49}$. Najpewniej więc wykluczenie oraczy z warstw składających hołd nastąpiło dopiero po narzuceniu im obowiązku wnoszenia wspomnianego wyżej czynszu przez księcia Albrechta Fryderyka (zapewne na krótko przed 1578 r.). Niespodziewanie w czasie hołdu w 1714 r. oracze jednak pojawili się na hołdzie określeni jako chłopi z wsi chłopskich (Pauerdorff) wraz z chłopami i sołtysami ze wsi czynszowych $^{50}$. Nie wiadomo, dlaczego chłopi złożyli tutaj hołd, dla nas ważne jest określenie ówczesnej pozycji społecznej oraczy już jednoznacznie jako chłopskiej.

Pod koniec XVIII w. osady oraczowskie określano po prostu jako królewskie wsie chłopskie (Königliche Bauerdorf) ${ }^{51}$. W związku z tym nie wyodrębniono oraczy w pełnej informacji o dobrach ziemskich i ich prawach w Prusach z 1804 r., kryli się najpewniej w grupie chłopów ${ }^{52}$. Nie zna tej warstwy również Robert

${ }^{44}$ Ostpr.Fol. 7862, f. 270.

${ }^{45}$ Ostpr.Fol. 7877.

46 J.F. Goldbeck, Topographie von Ost-Preußen, Teil I: Volständige Topographie vom Littauischen Cammer-Department, Königsberg und Leipzig 1785, s. 137.

${ }^{47}$ R. Stein, op.cit., s. 145.

${ }^{48}$ Erbhuldigungsakten des Herzogtums Preussen (cyt. EHP), 1 Th, hg. von H.H. Diehlmann, Hamburg 1980, s. 27-35; EHP, Th. 2, hg. von H.H. Diehlmann, Hamburg 1983, s. 195-205.

${ }^{49}$ EM 93a nr 2, f. 1-60: Registern von Adell, Freyen, Oratzen, Scholtzen, Krūgern, die F.D. geholdiget.

${ }^{50}$ EHP, Th. 3, hg. von H.H. Diehlmann, Hamburg 1992, s. 338-342.

${ }^{51}$ J.F. Goldbeck, op.cit., passim.

${ }^{52}$ Nachricht von den Ostpreussen befindlichen Landgütern, deren Rechten und Gerechtigkeiten, wie auch von den Einwohnern dieser Provinz, "Preussische-Brandenburgisch Miszellen", 1804, Jg. 1, 4. Quartal, 2. Heft, s. 418-442, przedruk w: N. v. Pock, Rechtsverhältnisse der Güter in Preussen im 18. Und 19. Jahrhundert. Ein Wiederabdruck zweier zeitgenössischer Darstellungen, “Altpreussische Geschlechterkunde. Neue Folge” 2009, Bd. 39, s. 341-350. 
Stein, solidny badacz stosunków wiejskich w Prusach Wschodnich w XVIII-XIX W., wymienia tylko königlichen Bauern ${ }^{53}$. W ten sposób dokonało się przejście warstwy oraczy z grupy ludności wolnej do poddańczej warstwy chłopskiej.

\section{ANEKS ŹRÓDŁOWY}

\section{III 1531}

Krzysztof von Zedwitz, starosta ksiązęcy z Ełku, informuje kancelarię ksiązęca o zasadach dziedziczenia dóbr oraczowskich w zwiqzku z puścizna w dobrach Dudki w okręgu etckim.

Oryginat w: GStAPK, EM 93d nr 22, f. 1, dokument dobrze zachowany, bez uszkodzeń, pismo czytelne, neogotyckie. Tekst wydano zgodnie z oryginatem, skróty rozwiazano bez zaznaczenia, usunięto podwójne , $n$ ', zamieniono , $v$ 'na , $u$ '.

Nota na odwrocie: [Bericht] de $\beta$ Lickischen gebietes uber dy vorsterben hueben zu Duttken [im Arischen ${ }^{54}[\text { sic! ] gelegen, montag nach Judica im } 31]^{55}$

Underrichtung in die canzerlei der verstorben preusch gutter halben im Lickischen gebiete im aratschen dienst zcur Duttken ${ }^{56}$ geleghen, welche gut keine handvesten haben. Sindt sy vor alders gehalden, wy ich den beffunden so der untter bey seinen leben dy seiner aus den guttern allenthalben entscheyden. Ader dy tochter mit der geben der brautschath einem man gegeben. Nach todlichen abgang der kinder vatter seindt dy gutter und ligende grunde am dy obersherschafft gefallen und so solcher ein erliches weyp nachgelassen. Ist dy jenigen mit kleyden und habendirwar aus den gutten geweysset und einer amptman m. g.h. dem Landesfurst dy verstorben hueben zu gebrauch eingenhomen. Auch wu czwene oder drey brueder nach todtlichen abschiedt des vatters nachgelassen und dy jhenigen dy gutter under dennander zutrennet und geteylet wu den einer von solchen bruedern mitt tode abgegangen seindt dy gutter auch an ire f.g. verstorben, doch der meynung das dy nachgelassen leibs erben und fruntschafft dy negsten zukauff sein sollen vor den fremden umb ein czimlische geld, ydoch stets alles zu irer f.g. willen ab sy den undertahnen dy verstorben hueben zu Duttken im Lickischen gepiets aus gnaden widerumb ein zcureumen oder geben beffohlen oder irer f.g. zcu gebrauch dem ampt behalden. Actum montag nach Judica im 1531.

Cristoff von Zcedewitz ${ }^{57}$ ampttman zur Lick ${ }^{58}$

${ }^{53}$ R. Stein, op.cit., s. 68-126.

${ }^{54} \mathrm{Z}$ pewnością pomyłka i błędne skojarzenie miejscowości Orzysz (Arys) z nazwą oraczy w tym dokumencie (aratschen).

${ }^{55}$ Część noty w nawiasie dopisana później innym atramentem.

${ }^{56}$ Dudki - miejscowość w powiecie ełckim, wówczas dobra oraczowskie.

${ }^{57}$ Krzysztof von Zedwitz, starosta ełcki, 1525-1548.

${ }^{58}$ Ełk - wieś czynszowa, siedziba starostwa, obecnie miasto. 


\title{
SOCIAL AND LEGAL CHANGES ON PRUSSIAN LANDS. THE ISSUE OF THE SO-CALLED PLOUGHMEN (XV-XVIII CENTURY)
}

\begin{abstract}
Ploughmen (German Pflüger) are a specific social group, which started functioning in the second half of the $15^{\text {th }}$ century exclusively in Ełk region in the State of the Teutonic Order in Prussia. The ploughmen were small freemen (German Freie) who had the duty to do ploughman service (horse and yoke) instead of armed military service. Initially, their social (and economic) position was close to that of the freemen. However, their standing was slightly lower in the eyes and minds of the contemporary citizens. The ploughmen possessed their estate without location privileges and instead Magdeburg rights were applied towards them. At the end of the $17^{\text {th }}$ century, the ploughmen were beginning to be made equal with corvée peasants due to their rising obligations (quit rents, tributes and labours). And finally, they were counted among the social strata of king's peasants (German königlichen Bauern) in the $18^{\text {th }}$ century.
\end{abstract}

\section{CHANGEMENTS SOCIO-LEGAUX SUR LES TERRITOIRES PRUSSIENS. LE PROBLEME DES SOI-DISANT LABOUREURS (XVE-XVIII ${ }^{\mathrm{E}}$ SIECLE)}

\section{Resumé}

Les laboureurs (Pflüger) était un groupe social spécifique qui - à partir de la seconde moitié du XVe siècle - fonctionnait uniquement dans le district d'Ełk de l'État teutonique de Prusse. Les laboureurs étaient les « petits libres » (Freie), qui, au lieu d'accomplir le service militaire obligatoire, étaient tenus de fournir leurs services de labour (cheval avec attelage). Initialement, leur position sociale (et économique) était proche de celle d'hommes libres, même si, dans la conscience des gens vivant à cette époque-là, elle était légèrement inférieure. Les propriétés des laboureurs ne jouissaient pas de privilèges découlant du droit urbain, mais étaient soumises au droit de Magdebourg simplifié. Vers la fin du XVII ${ }^{\mathrm{e}}$ siècle, en raison de charges croissantes (loyers, contributions et travail à prester), les laboureurs commencèrent à être égalisés avec les paysans de « Scharwerk » et, au XVIII ${ }^{\mathrm{e}}$ siècle, finirent par être classés comme les paysans royaux (königlichen Bauern). 